\title{
Professional practice assessment for minor head injury management in emergency department and clinical impact of a simulation-based training: Interventional study (before/after)
}

\author{
다 Pierre Vandingenen, M.D., ${ }^{1} \odot$ Anthony Chauvin, M.D., ${ }^{2}$ \\ (1) Nicolas Javaud, M.D., ${ }^{3}$ 다 Daniel Aiham Ghazali, M.D. ${ }^{4}$

\begin{abstract}
${ }^{1}$ Emergency Department and EMS, University Hospital of Poitiers, Poitiers-France ${ }^{2}$ Emergency Department and EMS, University Hospital of Lariboisière, Paris-France ${ }^{3}$ Emergency Department, University Hospital of Louis Mourier, Colombes-France

${ }^{4}$ Emergency Department and EMS, University Hospital of Bichat, Paris-France
\end{abstract}

\begin{abstract}
BACKGROUND: Minor head injury is a frequent reason for consultation in the emergency department. The use of computed tomography (CT) has increased dramatically in patients' care. Good time management implementation and interpretation are required. To study the level of agreement with recommendations for a minor head injury in emergency department management and the impacts of simulation-based training (SBT) on professional practice changes.

METHODS: Evaluation of professional practice for patient care in an emergency department according to the recommendations of the French Emergency Medicine Society (SFMU) established in 2012 before and after an SBT, including theoretical and simulation courses. It was based on the analysis of time to carry out a CT scan. It was also based on analysis of adherence to brain and spine scan indications and to hospitalization criteria.
\end{abstract}

RESULTS: The SBT carried out in the evaluation of the professional practices makes it possible to acquire the notion of urgency to obtain the CT Scan within one hour when the criteria are met $(p=0.007)$. Rater reliability for agreement with the hospitalization recommendations was better after SBT ( $p=0.03$, increased Kappa from 0.73 to 0.93$)$. On the other hand, there appeared to be a lack of essential information in the medical file, such as time of onset of head trauma.

CONCLUSION: Management of this type of patient appeared to be satisfactory. It can be improved by SBT on the basis of the SFMU 2012 consensus conference. There is a need to improve the software used by the emergency departments, which should include the time of trauma and recommendations. The association of the clinic and the biomarkers could help to limit the indications of the CT scan, and thus to have it organized more rapidly.

Keywords: Cervical spine; CT scan; emergency medicine minor head injury; evaluation of professional practice; hospitalization.

\section{INTRODUCTION}

Minor head injury $(\mathrm{MHI})$ is a frequent reason for emergency treatment with an estimated incidence in Europe of 235 per
100,000 people. ${ }^{[1]}$ When a patient is admitted to the emergency department (ED) for this reason, the primary goal of the emergency physician (EP) is to identify patients at risk for cranio-cerebral lesions based on anamnestic and clinical cri-

\footnotetext{
Cite this article as: Vandingenen P, Chauvin A, Javaud N, Ghazali DA. Professional practice assessment for minor head injury management in emergency department and clinical impact of a simulation-based training: Interventional study (before/after). Ulus Travma Acil Cerrahi Derg 2020;26:545-554.

Address for correspondence: Daniel Aiham Ghazali, M.D.

ED and EMS, University Hospital of Bichat, 46 Rue Henri Huchard, 75018 Paris, France.

Tel: 0033 |4025776I E-mail: danielaiham.ghazali@aphp.fr

Ulus Travma Acil Cerrahi Derg 2020;26(4):545-554 DOI: 10.14744/tjtes.2020.91589 Submitted: 19.06.2019 Accepted: 02.01.2020 Online: I5.05.2020

Copyright 2020 Turkish Association of Trauma and Emergency Surgery
} 
teria. ${ }^{[2]}$ The reference examination for the detection of these lesions is the computed tomography (CT) scan in bone and parenchymal sections. ${ }^{[2,3]}$ It can detect $8 \%$ to $15 \%$ of non-neurosurgical intracranial hemorrhagic lesions and fewer than $1 \%$ of lesions requiring a neurosurgical remedy according to the studies. $^{[4,5]}$ Indeed, the number of CT scans increased by $80 \%$ between 2000 and 2005 in the USA. ${ }^{[6]}$ In France, EDs have largely followed this trend with the resulting problems of radiation. ${ }^{[6]}$ This growth of the use of the CT scan nonetheless leads to questions about compliance with the recommendations without precautionary effect facilitated by easy access to this imagery. This situation may lead to excessive prescriptions because of fear of medical error. ${ }^{[6]}$ In addition, the contribution of an examination depends on good management of the time required to complete and interpret, and therefore on the use of the relevant examination within appropriate deadlines. However, access circuits to emergency CT scan lack fluidity. [6] At the same time, respect of the indications limits useless examinations and consequently overloads of the apparatuses and delay in patient care. ${ }^{[6]}$ Thus, $\mathrm{CT}$ is at the center of a public health debate establishing rules of prescription for. ${ }^{[7-10]}$ The management of $\mathrm{MHI}$ was defined in France by the 2012 consensus conference of the French Society of Emergency Medicine (SFMU). ${ }^{[9]}$ It was based on the National Institute for Health and Clinical Excellence (NICE) recommendations. ${ }^{\left[{ }^{[I]}\right.}$ In ED, a patient with $\mathrm{MHI}$ must receive an initial assessment within I5 minutes of arrival by the reception nurse or the EP. ${ }^{[12]}$ Glasgow Coma Scale (GCS) should be specified (with details) during this initial evaluation. ${ }^{[13]}$ In the ED of the University Hospital of Poitiers, there is a significant increase in the demand for scanners and especially CT-scan, while the radiology department cannot meet this demand. This situation contributes to very significant delays in obtaining the imagery and contributes to the saturation of the ED. An initial evaluation of professional practice in ED aimed to estimate the risk of cerebral or cervical spinal cord injury and to determine the indication of the $\mathrm{CT}$ and spinal scan as well as its completion time (Table I). We detected a non-respect of the French recommendations.

Table I. Indication of the CT scan in case of minor head injury

\begin{tabular}{|c|c|c|c|}
\hline $\begin{array}{l}\text { Indications of the CT scan } \\
\text { between } 4 \text { and } 8 \text { hours after } \\
\text { the trauma }\end{array}$ & $\begin{array}{l}\text { Indications of the CT scan } \\
\text { between } 4 \text { and } 8 \text { hours after } \\
\text { the trauma }\end{array}$ & $\begin{array}{l}\text { Indications of the CT scan } \\
\text { between } 4 \text { and } 8 \text { hours after } \\
\text { the trauma }\end{array}$ & $\begin{array}{l}\text { Indications of the CT scan } \\
\text { between } 4 \text { and } 8 \text { hours after } \\
\text { the trauma }\end{array}$ \\
\hline $\begin{array}{l}\text { - Focused neurological deficit } \\
\text { minutes before the trauma } \\
\text { (retrograde amnesia) } \\
\text { - Loss of consciousness } \\
\text { or amnesia of the facts } \\
\text { associated with } \\
\text { - a traumatic mechanism: } \\
\text { pedestrian overturned by a } \\
\text { motorized vehicle, patient } \\
\text { ejected from a vehicle or } \\
\text { falling from a height of } \\
\text { more than one meter } \\
\text { - or over the age of } 65 \\
\text { - Suspicion of open fracture of } \\
\text { the skull or embarrassment } \\
\text { - Any sign of fracture of } \\
\text { the base of the skull } \\
\text { (hemotympanum, } \\
\text { - bilateral periorbital bruise), } \\
\text { otorrhea or rhinorrhea } \\
\text { - of cerebrospinal fluid } \\
\text { (anticoagulant and/or } \\
\text { antiplatelet treatment) }\end{array}$ & $\begin{array}{l}\text { - Focused neurological deficit } \\
\text { - GCS score }<15 \text { at } 2 \text { hours of } \\
\text { trauma } \\
\text { - Suspicion of open fracture of } \\
\text { the skull or embarrassment } \\
\text { - Any sign of fracture of } \\
\text { the base of the skull } \\
\text { (hemotympanum, bilateral } \\
\text { periorbital bruise), } \\
\text { otorrhea or rhinorrhea of } \\
\text { cerebrospinal fluid } \\
\text { - More than one episode of } \\
\text { vomiting in adults } \\
\text { - Post-traumatic convulsion } \\
\text { - Treatment with Vitamin } \mathrm{K} \\
\text { antagonists (VKA) or other } \\
\text { anticoagulant medications }\end{array}$ & $\begin{array}{l}\text { - Patients unable to perform } \\
\text { active } 45^{\circ} \text { neck rotation (if } \\
\text { spinal mobilization can be } \\
\text { performeda) } \\
\text { - Cervical pain or contracture } \\
\text { in a patient over } 65 \text { years } \\
\text { - Trauma with high risk: fall of } \\
\text { more than I m or five steps, } \\
\text { axial impacts on the head } \\
\text { (diving), high-energy collision } \\
\text { a The maneuver can be done if } \\
\text { the accident of car with simple } \\
\text { rear shock, no embarrassment } \\
\text { in sitting position, walk } \\
\text { since the accident, absence } \\
\text { of cervical contracture or } \\
\text { secondary cervicalgia }\end{array}$ & $\begin{array}{l}\text { - Significant anomalies in the } \\
\text { scan } \\
\text { - GCS score <I5 after CT- } \\
\text { scan, whatever the result } \\
\text { - Impossibility of performing } \\
\text { CT scan despite its indication } \\
\text { (unavailability of CT scan, } \\
\text { transiently non-cooperating } \\
\text { patient) } \\
\text { - Persistence of severe } \\
\text { vomiting and/or headache } \\
\text { - Anticoagulant and/or } \\
\text { antiplatelet treatment } \\
\text { - Ethyl or medications } \\
\text { poisoning } \\
\text { - Suspicion of mistreatment } \\
\text { - Other reasons: social } \\
\text { isolation, unreliable } \\
\text { surveillance externally }\end{array}$ \\
\hline
\end{tabular}

GSC: Glasgow coma scale; CT: Computed tomography. 
Moreover, in some cases of $\mathrm{MHI}$, there is an indication of hospitalization for clinical monitoring (Table I) ${ }^{[4]}$ Education in the principles and practice of evidence-based practice is widely accepted as a core component of professional education for healthcare professionals. ${ }^{[14]}$ Our hypothesis is that simulationbased training (SBT) for EP would enhance professional practice by improving indications and the time to obtain $\mathrm{CT}$ and spinal scan, as well as respect for hospitalization's indications.

\section{MATERIALS AND METHODS}

\section{Setting}

This prospective, single-center, and interventional study analyzed the impacts of a simulation course on management of patients admitted to an ED for an MHI between I January 2017 and 31 July 2017. This study took place at the University Hospital of Poitiers, France. ED welcomes more than 40,000 patients each year. ${ }^{[15]}$ It includes a medical team of 34 doctors and 10 residents. The first phase of this study took place from January $1^{\text {st }}, 2017$, to March $31^{\text {th }}, 2017$. The first phase in the present study aimed to analyze the management of $\mathrm{MHI}$ and to identify areas for improvement during the course. The second phase of the study took place from May I, 2017 to July 3I, 2017 after training of physicians and residents. The aim in the second phase was to analyze the clinical impacts of the SBT on MHI management.

\section{Objectives}

In this study, the primary objective was to analyze the clinical impacts of theoretical training and simulation on the timeless characteristics of the CT scan according to the protocol on use of a scanner for an $\mathrm{MHI}$, and based on the codified recommendations made by the SFMU. ${ }^{[4]}$

Secondary objectives were to assess:

- Impacts of the course on agreement with the protocol on the use of a scanner for an MHI,

- CT scan indications and analysis of the outcome of patients who did not have a CT scan when it was indicated,

- Hospitalizations for MHI,

- Cervical spine scan carried out in patients with MHI,

- Management of the patients having anticoagulant and/or antiplatelet,

- Evaluation of the SBT.

\section{Population}

\section{Physicians and Residents}

Inclusion criteria: emergency physicians and residents working in the ED of the university hospital of the Poitiers.

Non-inclusion criteria: EPs and residents who could not be trained.

Exclusion criteria: emergency physicians and residents who never worked during one of the two assessment periods.

\section{Patients}

Eligible patients were patients admitted for an $\mathrm{MHI}$ in the ED of the university hospital of the Poitiers over the period of this study.

The inclusion criteria were patients aged 18 years or older who had an MHI according to the SFMU recommendations, following a fall, a road accident or an assault.

The non-inclusion criteria were severe head trauma, head trauma with associated extra-cranial lesions. Exclusion criteria were non-exploitable data (coding error, unspecified schedule of the brain injury), discharge against medical advice, and other reasons.

\section{Intervention}

We used an educational intervention to enhance uptake of a specific clinical protocol using the "GREET" reporting standards. ${ }^{[14]}$

\section{Definitions}

$\mathrm{MHI}$ is defined as an acute brain injury resulting from mechanical energy to the head from external physical forces associated with at least one of the following criteria: I) confusion or disorientation; 2) loss of consciousness for $\mathbf{3 0}$ minutes or less; 3) resolute post-traumatic amnesia estimated for less than 24 hours during ED consultation; 4) other transient neurological abnormalities, such as focal signs; 5) seizures and intracranial lesions that do not require surgery; 6) a Glasgow Coma Scale (GCS) score between 13 and I5, 30 minutes after the injury or later during the ED visit. The following time intervals were recorded: time (minutes) between the $\mathrm{MHI}$ and the arrival at the ED, time (minutes) before performing the scan.

\section{Theoretical and Simulation Course}

The SBT was conducted in the ED by AG (principal investigator) and PV (investigator) who have a university pedagogic diploma and are Directors of a Teaching Centre of Emergency Cares, with over six years' experience of teaching. The course was provided face to face with a ratio of four learners to one instructor. It was based on a 15-minute PowerPoint presentation (theoretical course) and two 60-minute simulated patient simulation sessions (practical course). The theoretical course presented a definition of $\mathrm{MHI}$ and risk for the patient if not correctly managed. Then, it addressed the 2012 consensus conference of the French Society of Emergency Medicine (SFMU) for MHI management. ${ }^{[4]}$ Learning objectives were: concerning Indications of the $\mathrm{CT}$ scan between four and eight hours after the trauma, indications in the hour after immediate request, Indications of the cervical spine scan, and indication to hospitalization (Table I). Finally, it incorporated the points of the recommendations not respected within the ED, aiming to focus on these points and their potential risk for the 
patient. This theoretical course was followed by a simulation session. Two scenarios were pre-established (the first one: a 20 years old helmeted biker and without antecedent, an accident at low speed in the city; the second one: an 86-year-old patient with anticoagulant who had a mechanical fall on the stairs). Each learner was an observer and participant in one of the two scenarios. Each 10-minute scenario was preceded by a briefing of five minutes and a debriefing of 15 minutes. At the end of the training, 15 minutes were dedicated to a summary, with the possibility of asking questions about $\mathrm{MHI}$ management. All in all, the training lasted 90 minutes. Written support summarizing recommendations for the management of $\mathrm{MHI}$ was issued at the end of the session (Table I). This training was mandatory for all doctors and residents. The SBT was evaluated by the participants concerning satisfaction and self-assessment of knowledge acquisition and a written test before and after training, 10 minutes before and 10 minutes after the training (Appendix I). Several training sessions were conducted over one month to train the entire team.

Evaluation of professional practices was conducted over two periods of three months before (period I) and after SBT (period 2). Period 2 began after all training sessions were completed. Physicians and residents were advised of the $\mathrm{MHI}$ management assessment in both periods but were not aware of the primary and secondary outcomes. The residents were asked during the two periods to immediately refer to the referring senior physician for all patients with an $\mathrm{MHI}$ they had seen so that they could manage the patient collaboratively.

\section{Main Outcome}

The main outcome was the percentage of patients meeting the I-hour or 8-hour imaging time frame and time frame for completion of imaging according to the time of $\mathrm{MHI}$.

\section{Secondary outcomes were}

- concordance between management concerning the recommended prescription of CT scan and cervical spine scan

- criteria for hospitalization for the surveillance of a minor brain injury

- analysis of the subgroup of patients with anticoagulant and/or antiplatelet

- objective evaluation of the SBT by a knowledge test before and after training and by self-assessment questionnaire.

\section{Data Collection}

The data of the patients admitted for MHI to the ED were carried out by NJ and MSJ using the ED's electronic medical record system RESURGENCES ${ }^{\circledR}$ database and its statistical tool using the S06.0 code (head injury) ${ }^{[16]}$ over the period concerned. For each $\mathrm{MHI}$, extracted data included: sex, age, mechanism, emergency arrival times, CT scan times, and clinical data.

\section{Statistics}

All anonymized data were analyzed using Statview ${ }^{\circledR} 4.5$ (SAS Institute Inc., Cary, NC). Quantitative variables were described by their median, Ist and 3rd interquartile range [QI; Q3]. Qualitative variables were described by number and percentage (n, \%). The comparative analysis of the quantitative variables used a Mann Whitney's non-parametric $U$ test. $\mathrm{Chi}^{2}$ test was used to compare qualitative variables. Rater reliability for the level of agreement with recommendations used Cohen's kappa. A value of $\mathrm{p}<0.05$ was considered.

\section{Ethics}

This study was considered as an evaluation of the professional practice by the Agence Nationale de Sécurité du Médicament (the French National Medication Safety Agency) and was approved by the ED committee on ethics of the University Hospital of Poitiers. In accordance with the instructions of the ethics committee, the patients were informed by the flyer. The emergency staff gave them an explanatory document. Then, the agreement of the patients (or family) was obtained verbally. All the data collected were recorded in the patient file with an anonymous number for each patient. This coding was independent of the identity of the participants and any information that could identify them. The doctors and the residents of the department were informed of the evaluation of the professional practices. The methodology was approved by the Statistic and Epidemiologic Research Center (INSERM-UI I53), Sorbonne Paris Cité (Paris, France), and statistical analysis was performed independently from the investigators by $A C$.

\section{RESULTS}

\section{Population}

\section{Emergency Physicians and Residents}

Thirty-four physicians and ten residents worked in the ED during both periods of this study. Thirty-two doctors and all residents were trained. Two doctors were off work during the training and were not included in this study. One doctor was excluded from this study, having left the service during the second period of this study. In total, the evaluation of professional practices involved 3 I doctors. The level of experience of physicians averaged six years $[2 ; 16]$.

\section{Patients}

One hundred and sixty-seven patients were eligible for the first phase of the evaluation of professional practices before training (period I) and 170 for the second phase following training (period 2). Ninety-two files were included in Period I and 83 in Period 2. Details are given in the flow chart (Fig. I).

The characteristics of the population studied during Period I and Period 2 are given in Table 2. The characteristics of the two excluded populations over the two periods were ana- 


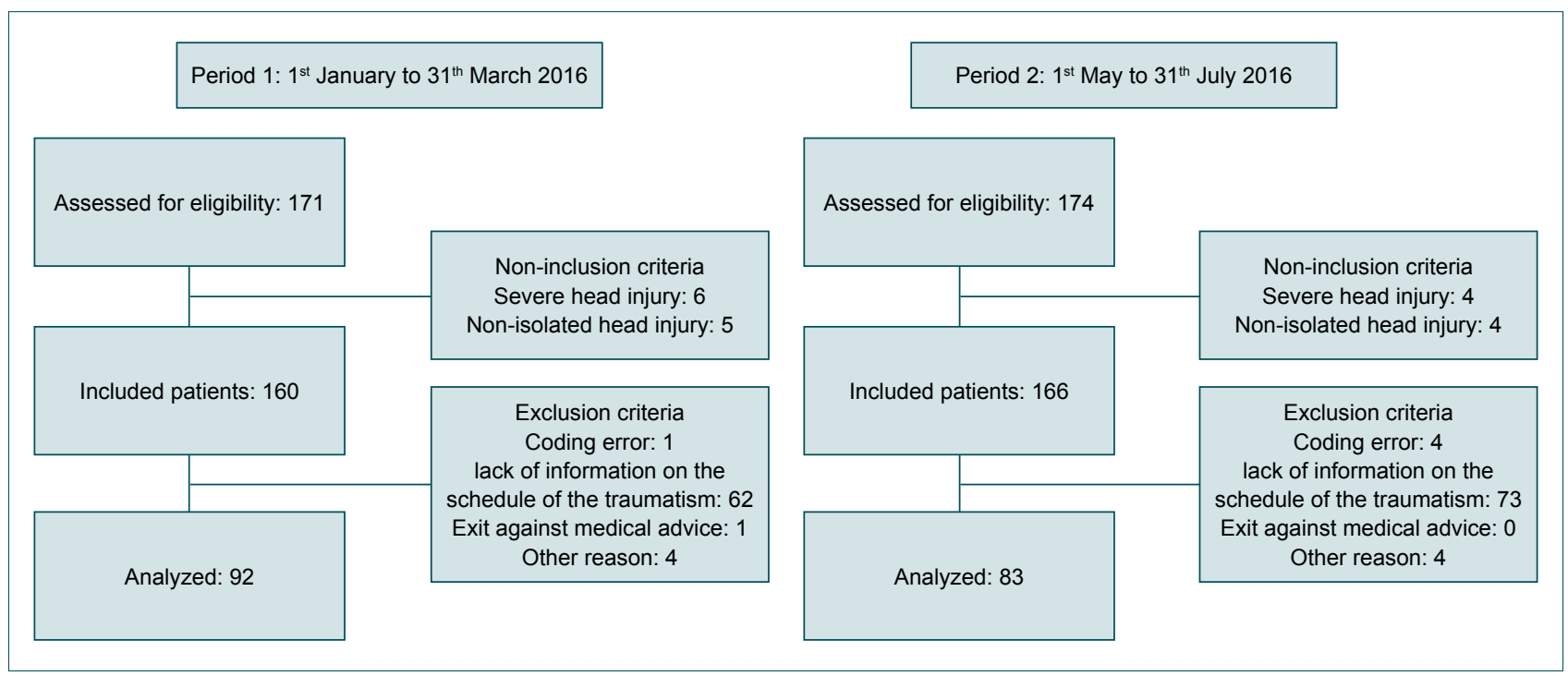

Figure 1. Flow chart.

lyzed because of a large number of exclusions. The excluded patients were similar in both periods: 37 men (49\%) during period I and $4 \mathrm{I}(47 \%)$ during period 2 . The average age over these two periods was 70 years [33; 84] and 69 years old, respectively [3I; 83].

\section{Main Outcome}

The timeliness of the CT scan was significantly improved by the training and implementation of the decision support protocol for scans to be completed within one hour. There was no difference for the time between trauma delay-emergency arrival in period I and period $2(p=0.33$ ) (Table 3). CT scan performed before $\mathrm{HI}$ after request according to the decisional algorithm represented $31.8 \%$ of cases (7 of 22 cases) in period I vs. $73.7 \%$ of cases (I7 out of 19 cases) in period 2 $(p=0.007)$. The number of CT scans indicated and performed in concordance with the consensus conference between $\mathrm{H} 4$ and $\mathrm{H} 8$ after the trauma was $55.6 \%$ ( 15 out of 27 cases) in

Table 2. Patient characteristics

\begin{tabular}{lcc}
\hline Characteristic & Period I & Period 2 \\
\hline $\begin{array}{l}\text { Demographic characteristics, n (\%) } \\
\quad \text { Population }\end{array}$ & $92(100)$ & $83(100)$ \\
$\quad$ Median age, [QI; Q3] & $69[35 ; 82]$ & $71[41 ; 84]$ \\
$\quad$ Male sex & $47(51)$ & $42(5 \mathrm{I})$ \\
Minor head injury mechanism, n (\%) & & \\
$\quad$ Fall & $68(74)$ & $60(73)$ \\
$\quad$ Road accident & $9(10)$ & $6(7)$ \\
Aggression & $14(15)$ & $16(19)$ \\
Other & I (I) & I (I) \\
\hline
\end{tabular}

Legend: [QI; Q3]: I ${ }^{\text {st }}$ and $3^{\text {rd }}$ interquartile range; MHI: minor head injury; Period I: assessment before the course; Period 2: assessment after the course. period I vs. $65.5 \%$ ( 17 of 26 cases) $(p=0.46)$ in period 2 . The times taken to perform the CT scan (in minutes) during the two periods are given in Table 3 . These delays were significantly improved for the scans to be performed within one hour ( $p=0.014)$ during period 2 compared to period I. There was no difference for the patients having to have the scanner within eight hours following the trauma $(p=0.23)$.

\section{Secondary Outcomes}

Indications of CT scan were considered correct if it was performed when indicated or not performed if it was not recommended. The CT scan indications were correct in $83.7 \%$ of the cases during period $I$ and in $85.5 \%$ of the cases during period 2. In period I, 10 patients did not have the CT scan, whereas it should have been done. For nine patients who could be contacted directly or through the GP, there was no complication. During period 2, seven patients did not have the scanner as recommended. One of them was hospitalized one day later for monocular blindness related to hemorrhage affecting the area of the optic nerve. For patients with anticoagulants or antiplatelet, there was $95.3 \%$ (37 out of 39 ) compliance with the indications during period I and 96.1\% (38 out of 40 ) during period $2(p=0.98)$. Indications for hospitalization to monitor $\mathrm{MHI}$ when justified were significantly improved in period 2 compared to period I ( $p=0.03)$. Non-performance of cervical imaging when it was not indicated was also improved in period $2(p=0.04)$ (Table 4a). All hospitalization situations that were not performed while recommended were those of patients with antiplatelet. Cohen's kappa was higher for all items in period 2 than in period I, especially for hospitalization recommendations $(0.73$ in period I vs. 0.93 in period 2) (Table 4b).

\section{DISCUSSION}

SBT significantly improved the time needed for "urgent" CT 
Table 3. The timeless characteristic of CT-scan in case of minor head injury

\begin{tabular}{|c|c|c|c|}
\hline Characteristic & Period I & Period 2 & $\mathbf{p}$ \\
\hline \multicolumn{4}{|l|}{ CT scan correctly indicated } \\
\hline Required within I hour (n) & 22 & 19 & \\
\hline Required within 8 hours (n) & 27 & 26 & \\
\hline \multicolumn{4}{|l|}{ Number of CT scan carried out } \\
\hline Within I hour, n (\%) & $7(31.8)$ & $17(73.7)$ & 0.007 \\
\hline Within 8 hours, n (\%) & $15(55.6)$ & $17(65.5)$ & 0.46 \\
\hline \multicolumn{4}{|l|}{ Time in minutes } \\
\hline Required CT-scan in the hour after immediate request, Median time [QI; Q3] & $99[46 ; 150]$ & $60[39 ; 91]$ & 0.014 \\
\hline Required CT-scan before 8 hours after the trauma, Median time [QI; Q3] & 499 [27I; 593] & $400[235 ; 518]$ & 0.23 \\
\hline Delay Trauma - emergency arrival, Median time [QI; Q3] & $|3|[74 ; 154]$ & $144[84 ; 169]$ & 0.33 \\
\hline
\end{tabular}

Legend: [QI; Q3]: I ${ }^{\text {st }}$ and $3^{\text {rd }}$ interquartile range; Period I: assessment before the course; Period 2: assessment after the course. CT: Computed tomography.

Table 4. Analysis of the indications to perform or not CT scan and cervical spine scan, and to monitor patients in case of minor head injuries before and after simulation-based training for emergency physicians and residents

\begin{tabular}{|c|c|c|c|c|c|}
\hline \multirow[t]{2}{*}{ (a) Percent agreement } & & \multicolumn{2}{|c|}{ Required } & \multicolumn{2}{|c|}{ Not required } \\
\hline & & Period I & Period 2 & Period I & Period 2 \\
\hline \multirow[t]{3}{*}{ CT scan } & In theory (n) & 59 & 52 & 33 & 31 \\
\hline & In practice (n) & 49 & 45 & 28 & 26 \\
\hline & $P$ & \multicolumn{2}{|c|}{0.61} & \multicolumn{2}{|c|}{1} \\
\hline \multirow[t]{3}{*}{ Cervical spine scan } & In theory $(n)$ & 23 & 28 & 69 & 55 \\
\hline & In practice (n) & 15 & 15 & 55 & 51 \\
\hline & $P$ & \multicolumn{2}{|c|}{0.40} & \multicolumn{2}{|c|}{0.04} \\
\hline \multirow[t]{3}{*}{ Hospitalization } & In theory (n) & 54 & 48 & 38 & 37 \\
\hline & In practice (n) & 46 & 47 & 35 & 35 \\
\hline & $P$ & \multicolumn{2}{|c|}{0.03} & \multicolumn{2}{|c|}{ I } \\
\hline \multirow[t]{2}{*}{ (b) Rater reliability using Cohen's kappa } & & \multicolumn{2}{|c|}{ Theory (Period I) } & \multicolumn{2}{|c|}{ Theory (Period 2) } \\
\hline & & Required & Not required & Required & Not required \\
\hline \multirow[t]{3}{*}{ CT scan in practice } & Carried out & 49 & 5 & 45 & 5 \\
\hline & Not carried out & 10 & 28 & 7 & 26 \\
\hline & Kappa & \multicolumn{2}{|c|}{0.66} & \multicolumn{2}{|c|}{0.70} \\
\hline \multirow[t]{3}{*}{ Cervical spine scan in practice } & Carried out & 15 & 14 & 15 & 4 \\
\hline & Not carried out & 8 & 55 & 13 & 51 \\
\hline & Kappa & \multicolumn{2}{|c|}{0.41} & \multicolumn{2}{|c|}{0.51} \\
\hline \multirow[t]{3}{*}{ Hospitalization in practice } & Carried out & 46 & 3 & 47 & 2 \\
\hline & Not carried out & 8 & 35 & 1 & 35 \\
\hline & Kappa & \multicolumn{2}{|c|}{0.76} & \multicolumn{2}{|c|}{0.93} \\
\hline
\end{tabular}

CT: Computed tomography.

scans to be performed within one hour of medical prescription. On the other hand, the course did not show any improvement in the time taken for CT scan to be performed between four and eight hours after the head trauma. SBT also helped to make EPs more aware of the criteria for hospitalization and the criteria of gravity requiring appropriate 
monitoring. The training significantly limited unjustified spinal imaging. Participants were satisfied with the training, which objectively improved their theoretical knowledge.

Our study showed that SBT based on an initial evaluation of professional practices significantly shortened the time to perform a CT scan in MHI. The circumstances of head trauma occurrence were dominated by falls $(74 \%$ in the first phase and $73 \%$ in the second phase), as described in some European studies. ${ }^{[17-19]}$ Despite the existence of recommendations on the management of cranial trauma and prescription rules for scan, its application was not always respected; they were observed in almost $85 \%$ of cases. Even if strict adherence to the guidelines does not provide full protection against malpractice claims, its application improves the quality of management in an ED and reduces adverse outcomes. A very recent retrospective study based on Canadian CT guidelines ${ }^{[20]}$ noted an unjustified number of CT scans of $10.9 \%$ overall and $37.3 \%$ for the patients under $65 . .^{[2]]}$ Another prospective multicenter study estimated this rate at $27 \% .{ }^{[2]}$ An American, retrospective study assessed compliance with the rules adopted by the American College of Emergency Medicine for prescribing the CT scan in case of minor brain injury, and it showed that the rules were applied for $75.5 \%$ of the patients. ${ }^{[23]}$ The decision of whether or not to perform a CT scan notwithstanding knowledge of the consensus conference on minor brain injury management may be influenced by clinical and non-clinical factors. ${ }^{[24-26]}$ Such management decisions have an impact on the functioning of a department: a significant increase in the use of CT in traumatic conditions over the past decade has resulted in longer times in ED for patients, as well as increased health care costs and unnecessary exposure to irradiations. ${ }^{[2]]}$

The notion of urgency to scan within one hour after prescription, when the relevant criteria were fulfilled, was accepted. ${ }^{[4]}$ However, this was not the case concerning the CT scan to be carried out between four and eight hours following MHI. Several parameters could intervene: the time of head trauma may not have been noted. Our analysis made it possible to identify the first area in need of improvement. The software package could be enhanced by adding an alert or a time slot so that this information is obligatorily notified and not lost. Moreover, access to the support given during the training, posters and computerized access to the protocol recalling recommendations for $\mathrm{MHI}$ management (Table I) in emergencies should be set up. ${ }^{[4]}$ Another difficulty could consist of access to the scanner extraneous to the particular case allowing a scan to be performed within one hour. Access circuits to emergency CT scans lack fluidity (busy hours on weekdays, absence of dedicated machines, organizational problems that make emergencies interfered with programmed activity on the scanner). ${ }^{[6]}$ In addition, this access can be slowed by the involvement of non-emergency responders, such as the stretcher-bearer, the radiological manipulator and the radiologist himself, who may not be sufficiently aware of this notion of delay. Several axes could be envisaged to improve the fluidity of the circuit from the patient to the scanner. First, this training could be extended to the radiology department. Actions could be taken to simplify the scanner access circuit. For example, some emergency and radiology departments have recommended bringing patients to radiology without prior discussion between an emergency physician and a radiologist for a CT scan. This practice, currently customary for standard X-rays, would limit the elements rendering this examination difficult to perform within the recommended time limits. Authors have suggested the use of biomarkers, such as the $\mathrm{S}-100 \mathrm{~B}$ protein assay in adults as an aid to the diagnosis of lesions in case of head trauma; ${ }^{[28,29]}$ they have shown a very strong negative predictive value, close to $100 \%{ }^{[30]}$ Routine use of this marker would quickly rule out any brain damage, at no risk for the patient, and thereby avoid approximately $30 \%$ of unnecessary CT scan ${ }^{[30]}$ However, this biomarker rapidly decreases and quickly loses its negative predictive value and sensitivity if not used early. ${ }^{[3]}$ Through the initial evaluation, this study determined areas needing improvement. First, the undiagnosed complication in one patient due to lack of a CT-scan confirmed the need for strict compliance with the recommendations. In addition, the first phase of the study revealed non-compliance with the indications for spinal imaging and hospitalization. This analysis helped to focus on these important points during the training. The scores significantly improved on account of the training, and they were confirmed by a change in professional practice during the second, evaluated phase of the study, as well as the clinical impacts for the patient. Few studies have analyzed the clinical impacts of an SBT. In Kirkpatrick's pyramid, there are 4 levels of evaluation for a course: level I: satisfaction of the participants, level 2: acquisition of knowledge, skills, and attitude, level 3: changes in professional practices, and level 4: clinical impacts for the patient. ${ }^{[32,33]}$ Level 4 (patient outcomes) is poorly studied in studies evaluating training, including simulation. ${ }^{[34,35]}$ In addition to the improvement in CT scan times, other clinical impacts on the patient have been observed: respect for hospitalization criteria and conditions for cervical spine scan. A very recent study has shown that in the anticoagulant or antiplatelet population, the error was more related to the indication of hospitalization than to CT scan indication. ${ }^{[36]}$ Our SBT revealed these errors and corrected them during simulation training. Based on Cohen's kappa interpretation, ${ }^{[3]}$ it was improved from the moderate level in period I to almost perfect level in period 2 meaning that rater reliability for the level of agreement with the recommendations was better after SBT. However, even after the training, there was one case of non-hospitalization despite antiplatelet treatment. Alert implementation in the software used in the ED in case of antiplatelet or anticoagulant treatment could help to limit this type of error. Easier access to the consensus conference in the software could also help to systematize compliance with the recommendations. Finally, this evaluation revealed that $39.7 \%$ of patient data in period $I$ and $46.3 \%$ in period 2 could not be used due to lack of information. This was related to the trauma schedule, in which four of the records failed to 
report on clinical examination, and only gave CT scan results. Indeed, they could not determine the time elapsed between the trauma and the use of the scanner, thereby leading to undetected errors.

\section{Limitations}

This monocentric study limits its external validity. ${ }^{[23,38]}$ This study was carried out in a university hospital center where the CT scan is not performed without prior discussion between emergency physician and radiologist. These data cannot be generalized to hospitals where the CT scan is more systematically carried out. Finally, some general hospital centers only have one emergency doctor (especially during the night). Thus, time elapsed could be higher. Another limitation of this study was the change of residents during the study period. Nevertheless, to attenuate this bias, the residents who participated in period $I$ and 2 had a similar experience, received the $S B T$, and were asked to immediately refer to the $\mathrm{EP}$ for each patient with MHI.

\section{Conclusion}

Clinical impacts of SBT on patients with MHI were assessed: an SBT combining theoretical course and practical simulation significantly improved MHI management. Areas for future improvement concern CT scan to be performed within eight hours and the contents of medical records, including schedules. Improvements to the software used in EDs, with access to consensus conferences and visual alarms, could help. This evaluation of professional practices has shown that although the indications for CT scan appear to be accepted, there is a lack of performance concerning strict compliance with deadlines, as well as indications for cervical scan and hospitalization when monitoring is required.

Availability of Supporting Data: The data supporting statistic findings are included in the manuscript. Please contact the corresponding author for other data requests.

Ethics Committee Approval: This study was considered as an evaluation of the professional practice by the Agence Nationale de Sécurité du Médicament (the French National Medication Safety Agency) and did not need ethical approval. It was approved by the local Emergency Department committee on ethics of the University Hospital of Bichat. All patients were verbally informed that their medical data should be used for the present study under an anonymous number. Data were not used in case of patient refusal.

Peer-review: Internally peer-reviewed.

Authorship Contributions: Concept: D.A.G.; Design: D.A.G.; Supervision: D.A.G.; Materials: P.V., D.A.G.; Data: P.V.; Analysis: D.A.G., A.C.; Literature search: P.V., N.J., D.A.G.; Writing: P.V., D.A.G.; Critical revision: A.C., N.J.

Conflict of Interest: None declared.

Financial Disclosure: The authors declared that this study has received no financial support.

\section{REFERENCES}

1. Brain injury epidemiology in Europe. Acta Neurochir (Wien) 2006;148:255-68. [CrossRef]

2. Mishra RK, Munivenkatappa A, Prathyusha V, Shukla DP, Devi BI. Clinical predictors of abnormal head computed tomography scan in patients who are conscious after head injury. J Neurosci Rural Pract 2017;8:64-7.

3. Stein SC, Ross SE. Minor head injury: A proposed strategy for emergency management. Ann Emerg Med 1993;22:1193-6. [CrossRef]

4. Jehlé E, Honnart D, Grasleguen C, Bouget J, Dejoux C, Lestavel P, et al. Minor head injury (Glasgow Coma Score 13 to 15): triage, assessment, investigation and early management of minor head injury in infants, children and adults. Ann Fr Med Urg 2012;2:199-214. [CrossRef]

5. Bruns JJ Jr, Jagoda AS. Mild traumatic brain injury. Mt Sinai J Med 2009;76:129-37. [CrossRef]

6. Schouman-Claeys E. Emergency imaging and CT. [Article in French]. J Radiol 2007;88:529-30. [CrossRef]

7. Stiell IG, Wells GA, Vandemheen K, Clement C, Lesiuk H, Laupacis A, et al. The Canadian CT Head Rule for patients with minor head injury. Lancet 2001;357:1391-6. [CrossRef]

8. Smits M, Dippel DW, de Haan GG, Dekker HM, Vos PE, Kool DR, et al. Minor head injury: guidelines for the use of CT--a multicenter validation study. Radiology 2007;245:831-8. [CrossRef]

9. Haydel MJ, Preston CA, Mills TJ, Luber S, Blaudeau E, DeBlieux PM. Indications for computed tomography in patients with minor head injury. N Engl J Med 2000;343:100-5. [CrossRef]

10. Miller EC, Holmes JF, Derlet RW. Utilizing clinical factors to reduce head CT scan ordering for minor head trauma patients. J Emerg Med 1997;15:453-7. [CrossRef]

11. National Collaborating Centre for Acute Care (UK). Head Injury: Triage, Assessment, Investigation and Early Management of Head Injury in Infants, Children and Adults. London: National Collaborating Centre for Acute Care (UK); 2007.

12. French Society of Emergency Medicine. Repository 2004 for the triage nurse (Référentiel IOA). Available from: URL: www.sfmu.org/upload/ referentielsSFMU/ioa2004.pdf. Accessed April 8, 2018.

13. Türedi S, Hasanbasoglu A, Gunduz A, Yandi M. Clinical decision instruments for CT scan in minor head trauma. J Emerg Med 2008;34:253-9.

14. Phillips AC, Lewis LK, McEvoy MP, Galipeau J, Glasziou P, Moher D, et al. Development and validation of the guideline for reporting evidencebased practice educational interventions and teaching (GREET). BMC Med Educ 2016;16:237. [CrossRef]

15. Official website of the University Hospital of Poitiers. Available from: URL: http://www.chu-poitiers.fr/specialites/urgences/en/. Accessed April 8, 2018.

16. WHO. International Statistical Classification of Diseases and Related Health Problems 10th Revision. 2016. Available from: URL: http:// apps.who.int/classifications/icd10/browse/2016/en\#/. Accessed April 8, 2018 .

17. Alaranta H, Koskinen S, Leppänen L, Palomäki H. Nationwide epidemiology of hospitalized patients with first-time traumatic brain injury with special reference to prevention. Wien Med Wochenschr 2000;150:444-8.

18. Andersson EH, Björklund R, Emanuelson I, Stålhammar D. Epidemiology of traumatic brain injury: a population based study in western Sweden. Acta Neurol Scand 2003;107:256-9. [CrossRef]

19. Kleiven S, Peloso PM, von Holst $H$. The epidemiology of head injuries in Sweden from 1987 to 2000. Inj Control Saf Promot 2003;10:173-80.

20. Papa L, Stiell IG, Clement CM, Pawlowicz A, Wolfram A, Braga C, et al. Performance of the Canadian CT Head Rule and the New Orleans 
Criteria for predicting any traumatic intracranial injury on computed tomography in a United States Level I trauma center. Acad Emerg Med 2012;19:2-10. [CrossRef]

21. Klang E, Beytelman A, Greenberg D, Or J, Guranda L, Konen E, et al. Overuse of Head CT Examinations for the Investigation of Minor Head Trauma: Analysis of Contributing Factors. J Am Coll Radiol 2017;14:171-6. [CrossRef]

22. Ro YS, Shin SD, Holmes JF, Song KJ, Park JO, Cho JS, et al; Traumatic Brain Injury Research Network of Korea (TBI Network). Comparison of clinical performance of cranial computed tomography rules in patients with minor head injury: a multicenter prospective study. Acad Emerg Med 2011;18:597-604. [CrossRef]

23. DeAngelis J, Lou V, Li T, Tran H, Bremjit P, McCann M, et al. Head CT for Minor Head Injury Presenting to the Emergency Department in the Era of Choosing Wisely. West J Emerg Med 2017;18:821-9. [CrossRef]

24. Melnick ER, Shafer K, Rodulfo N, Shi J, Hess EP, Wears RL, et al. Understanding Overuse of Computed Tomography for Minor Head Injury in the Emergency Department: A Triangulated Qualitative Study. Acad Emerg Med 2015;22:1474-83. [CrossRef]

25. Miglioretti DL, Johnson E, Williams A, Greenlee RT, Weinmann S, Solberg LI, et al. The use of computed tomography in pediatrics and the associated radiation exposure and estimated cancer risk. JAMA Pediatr 2013;167:700-7. [CrossRef]

26. Smith-Bindman R, Lipson J, Marcus R, Kim KP, Mahesh M, Gould R, et al. Radiation dose associated with common computed tomography examinations and the associated lifetime attributable risk of cancer. Arch Intern Med 2009;169:2078-86. [CrossRef]

27. Korley FK, Pham JC, Kirsch TD. Use of advanced radiology during visits to US emergency departments for injury-related conditions, 1998-2007. JAMA 2010;304:1465-71. [CrossRef]

28. Beaudeux JL, Laribi S. S100B protein serum level as a biomarker of minor head injury. [Article in French]. Ann Biol Clin (Paris) 2013;71:71-8.
29. Springborg JB, Undén J, Ingebrigtsen T, Romner B. Brain injury marker S100B can reduce the use of computer tomography in minor head injuries--secondary publication. [Article in Danish]. Ugeskr Laeger 2009;171:978-81.

30. Laribi S, Kansao J, Borderie D, Collet C, Deschamps P, Ababsa R, et al; Stic-S100 Study Groupa. S100B blood level measurement to exclude cerebral lesions after minor head injury: the multicenter STIC-S100 French study. Clin Chem Lab Med 2014;52:527-36. [CrossRef]

31. Zongo D, Ribéreau-Gayon R, Masson F, Laborey M, Contrand B, Salmi LR, et al. S100-B protein as a screening tool for the early assessment of minor head injury. Ann Emerg Med 2012;59:209-18. [CrossRef]

32. Kirkpatrick DL. Evaluation of training. In: Craig RL, Bittel LR, editors. Training and Development Handbook. New York: McGraw Hill; 1967. p. $87-112$.

33. Smidt A, Balandin S, Sigafoos J, Reed VA. The Kirkpatrick model: A useful tool for evaluating training outcomes. J Intellect Dev Disabil 2009;34:266-74. [CrossRef]

34. Zendejas B, Brydges R, Wang AT, Cook DA. Patient outcomes in simulation-based medical education: a systematic review. J Gen Intern Med 2013;28:1078-89. [CrossRef]

35. Ghazali DA, Choquet C, Casalino E. Simulation-based training for triage of HIV exposures in the emergency department. Med Educ 2019;53:521-2. [CrossRef]

36. Chapin M. Assessment of minor head injuries in emergencies departments (Evaluation des traumatismes crâniens légers aux urgencies). Medical thesis 2016, University of Rouen, France. Available from: URL: https://dumas.ccsd.cnrs.fr/dumas-01381274/document. Accessed April 8, 2018.

37. McHugh ML. Interrater reliability: the kappa statistic. Biochem Med (Zagreb) 2012;22:276-82. [CrossRef]

38. Wennberg JE. Unwarranted variations in healthcare delivery: implications for academic medical centres. BMJ 2002;325:961-4. [CrossRef]

\title{
ORİJINAL ÇALIŞMA - ÖZET
}

\section{Acil serviste hafif kafa travması yönetimi için profesyonel uygulamanın değerlendirilmesi ve simülasyon tabanlı eğitimin klinik etkisi: Girişimsel çalışma “öncesi-sonrası” \\ Dr. Pierre Vandingenen, ${ }^{1}$ Dr. Anthony Chauvin, ${ }^{2}$ Dr. Nicolas Javaud, ${ }^{3}$ Dr. Daniel Aiham Ghazali ${ }^{4}$}

\begin{abstract}
${ }^{1}$ Poitiers Üniversite Hastanesi, Acil Servis Bölümü ve EMS, Poitiers-Fransa
${ }^{2}$ Laribisière Üniversite Hastanesi, Acil Servis Bölümü ve EMS, Paris-Fransa

${ }^{3}$ Louis Mourier Üniversite Hastanesi, Acil Servis Bölümü, Colombes-Fransa

${ }^{4}$ Bichat Üniversite Hastanesi, Acil Servis Bölümü ve EMS, Paris-Fransa
\end{abstract}

AMAÇ: Hafif kafa travması acil servise (AS) konsültasyon için sık başvurulma nedenidir. Bilgisayarlı tomografı (BT) kullanımı hastaların bakımını önemli ölçüde iyileştirmiştir. lyyi bir zaman yönetimi ve yorumu gereklidir. Bu yazıda, AS yönetiminde hafif kafa travması önerilerine uyum düzeyi ve simülasyon temelli bir eğitimin (SBT) profesyonel uygulama değişiklikleri üzerindeki etkisi incelendi.

GEREÇ VE YÖNTEM: Bir AS'de, SBT öncesinde ve sonrasında hasta bakımı için profesyonel uygulamanın 20 I2 yılında kurulan Fransız Acil TıP Derneği'nin (Société Française de Médecine d’Urgence: SFMU) önerilerine göre teorik ve simülasyon kurslarını içeren değerlendirmesi yapıldı. BT taraması yapmak için zaman analizine, ayrıca beyin ve omurga tarama endikasyonlarına ve hastaneye yatış kriterlerine uyum analizine dayanıyordu. BULGULAR: Mesleki uygulamaların değerlendirilmesinde gerçekleştirilen SBT, kriterleri karşıladığında bir saat içinde BT taraması sonucunu alma açııından aciliyet kavramını edinmeyi mümkün kılmaktadır $(p=0.007)$. SBT'den sonra hastaneye yatış önerilerine uyumuna ilişkin değerlendirici güvenilirliği daha iyi idi ( $p=0.03$, Kappa'yı 0.73 'den 0.93 'e yükseltti). Öte yandan, tıbbi dosyada kafa travmasının oluş zamanı gibi temel bilgilerin eksik olduğu ortaya çıktı.

TARTIŞMA: Bu tip hastanın yönetimi tatmin edici görünmektedir. SBT tarafından SFMU 2012 uzlaşı konferansı temelinde SBT uygulanarak bu durum geliştirilebilir. Acil servisler tarafından kullanılan ve travma zamanını ve önerileri içermesi gereken yazılımı geliştirmeye ihtiyaç vardır. Klinik ve biyobelirteçlerin birlikteliği BT taramasının endikasyonlarını sınırlamaya ve böylece daha hızlı organize edilmesine yardımcı olabilir. Anahtar sözcükler: Acil tıp; BT taraması; hafif kafa travması; hastaneye yatış; mesleki uygulamaların değerlendirilmesi; servikal omurga.

Ulus Travma Acil Cerrahi Derg 2020;26(4):545-554 doi: 10.14744/tjtes.2020.91589 


\section{Appendix I: QUESTIONNAIRE PRE/POST-TRAINING}

\section{Management of minor head injuries in Emergency Department}

QUESTION I: Check the correct answer(s) concerning the factors to be checked immediately (maximum within one hour of the request)

- A: anticoagulant treatment

- B: antiplatelet treatment

- C: vomiting

- D: GCS score $<15$ one hour after head trauma

- E: post-trauma convulsions

QUESTION 2: Check the correct answer(s) for the factors that should be taken into consideration to make cervical spine scan

- A: fall of less than 5 steps

- B: Inability to perform active rotation of the neck by $45^{\circ}$

- C: patient over 65 years old

- D: pain or contracture in a patient over 65 years old

- E: 3 m drop

\section{QUESTION 3: Check the correct answer (s) for hospitalization criteria for minor head injuries:}

- A: impossibility to perform the brain scan even if the indication is required

- B: associated intoxication (drug, alcohol, ...)

- C: normal scan at 6 hours after head trauma

- D: anticoagulant treatment

- E: antiplatelet treatment

\section{QUESTION 4: Check the correct answer (s) for the risk factors leading to performance of a CT scan:}

- A: high kinetic energy in road traffic injury

- B: patient over 65 years old

- C: focused neurological deficit

- D: amnesia of facts in a 40-year-old patient

- E: otorrhagia

QUESTION 5: Check the correct answer (s) for the management of patients with minor head injuries:

- A: a pregnancy test must be performed beforehand in pregnant women if a CT scan is to be performed

- B: in cervical trauma of medium gravity, cervical spine X-ray should be preferred

- C: at least $24 \mathrm{~h}$ monitoring is required for patients with head trauma if they have an anticoagulant or antiplatelet treatment

- D: CT scan is mandatory in a patient with head trauma associated with drug intoxication

- E: a head trauma with a normal early scan does not require monitoring

\section{RESPONSES}
I. $A C E$
2. $B D E$
3. $A B D E$
4. $\mathrm{ACE}$
5. C
6. $\mathrm{C}$ 